\title{
A Proper Manner of Carrying on Controversies: Richard Price and the American Revolution
}

\author{
Emma Macleod
}

\begin{abstract}
A B S T R ACT In the emerging spectrum of British "friendship to liberty" over the period $1773-78$, it is possible to see the British political writer and philosopher Richard Price as either in the radical pro-American camp or among the more moderate "Friends of America." This essay locates the solution to Price's apparent inconsistency in an approach recently developed by historians of the 1790 s, which suggests that we should not expect consistency from contemporaries responding to a train of events and with a range of interlocutors. It argues that Price was at core a radical pro-American, but that his closeness to the Earl of Shelburne, the trajectory of the Anglo-American crisis during the 1770s, and Price's own temperamental dislike of ruptures of friendship combined to suggest a greater apparent sympathy with moderate pro-Americanism before the death of the Earl of Chatham in 1778. KEY WORD S: eighteenth-century news networks; Whig views of American independence; American Revolutionary War; radicalism in the 1770 ond 1780 s; friendship and civility
\end{abstract}

\begin{abstract}
N "AMERICA IS THE COUNTRY to which most of the friends of liberty in this nation are now looking," the British philosopher and political writer Richard Price wrote to an American correspondent in November 1773. ${ }^{1}$ In late 1773 , the spectrum of what it could mean for Britons to be "friends of liberty" in the context of the American crisis had yet to emerge. Within five years, however, as British sympathizers with the Patriot cause responded to increasingly coercive government policies, the resulting American Declaration of Independence, and the war, which by 1778 offered little promise of victory to the British government, their views about the ideal form for the Anglo-American relationship openly diverged. Followers of the Earl of Chatham continued to argue that reconciliation and a reformed imperial relationship were
\end{abstract}

1. Richard Price to Henry Marchant, November 2, 1773, in The Correspondence of Richard Price, ed. D. O. Thomas and W. Bernard Peach, 3 vols. (Durham, N.C., 1983-94) [hereafter CRP], 1:164.

HUNTINGTON LIBRARY QUARTERLY | VOL. 82, NO. 2

Pp. 277-302. (2)19 by Henry E. Huntington Library and Art Gallery. ISSN 0018-7895 | E-ISSN 1544-399x. All rights reserved. For permission to photocopy or reproduce article content, consult the University of Pennsylvania Press Rights and Permissions website, http://www.upenn.edu/pennpress/about/permissions.html. 
optimal for both parties. Supporters of the Earl of Shelburne, Chatham's protégé and successor in his political grouping, together with followers of the Marquis of Rockingham, eventually accepted that the separation of America from Britain was inescapable and should be managed by developing plans for mutual commercial benefit. Other, more radical "friends of liberty" positively applauded American independence and hoped to see the establishment and development of a republic of liberty on the other side of the Atlantic Ocean. ${ }^{2}$

Despite this variety of ideas about the resolution of the American crisis among British opponents of government policy, much historical writing treats them as a single if heterogeneous group of "Friends of America." This has the advantage of encompassing the range of opinions hostile to the policy of suppressing the colonial rebellion by force, but it fails to take sufficient notice of the very significant difference between British sympathizers who accepted American independence as inevitable but regrettable, and those who came positively to welcome it. It also tends to treat the views of any one individual as relatively settled and consistent. Richard Price's sympathy for the American colonists is usually located at the radical end of this spectrum, and there is of course very good evidence to support this view. 3 In June 1783, for example, he claimed to the American Patriot Benjamin Rush that

The struggle has been glorious on the part of America; and it has now issued just as I wished it to issue; in the emancipation of the American states and the establishment of their independence. It is not possible for me to express to you the satisfaction this has given me. I think it one of the most important revolutions that has ever taken place in the world. 4

This understanding of Price's position does not, however, take into account evidence that, as John Faulkner noted, suggests a more Shelburnite or even Chathamite cast to

2. For example, Frank O’Gorman, “The Parliamentary Opposition to the Government's American Policy 1760-1782," in Britain and the American Revolution, ed. H. T. Dickinson (Harlow, U.K., 1998), 97-123; H. T. Dickinson, “'The Friends of America': British Sympathy with the American Revolution," in Radicalism and Revolution in Britain 1775-1848, ed. Michael T. Davis (Basingstoke, U.K., 2000), 1-29; Jerome R. Reich, British Friends of the American Revolution (London, 1998); Marie Peters, The Elder Pitt (Harlow, U.K., 1998), 216-25; L. G. Mitchell, Charles James Fox (Oxford, 1992), 25-46; and Frank O'Gorman, The Rise of Party in England: The Rockingham Whigs 1760-82 (London, 1975), 315-95.

3. Carl B. Cone, Torchbearer of Freedom: The Influence of Richard Price on Eighteenth Century Thought (Lexington, Ky., 1952); Colin Bonwick, English Radicals and the American Revolution (Chapel Hill, N.C., 1977); D. O. Thomas, Richard Price and America (Aberystwyth, U.K., 1975); Thomas, The Honest Mind: The Thought and Work of Richard Price (Oxford, 1977); J. G. A. Pocock, "Radical Criticisms of the Whig Order in the Age between Revolutions," in The Origins of Anglo-American Radicalism, ed. Margaret C. Jacob and James R. Jacob (London, 1984), 33-57 at 46; H. T. Dickinson, "Richard Price on Reason and Revolution," in Religious Identities in Britain, 1660-1832, ed. William Gibson and Robert G. Ingram (Aldershot, U.K., 2005), 231-54.

4. Price to Rush, June 26, 1783, CRP, 2:185. 
his thinking on America. 5 Most significantly, Price initially hoped for a federal solution rather than complete separation. This essay offers an explanation for this apparent inconsistency in Price's stated opinions and locates the solution in an approach recently developed for understanding British political thinking in the 1790 .

The history of political ideas has been greatly influenced since the 1960s by the "Cambridge School"-associated with scholars such as Quentin Skinner, John Dunn, and J. G. A. Pocock-and its insistence that texts must be understood in the context in which they were written. ${ }^{6}$ The debate over the political consistency or otherwise of Edmund Burke, for instance, is no longer pursued with such heat as it was before the last decades of the twentieth century. While some historians argue that there was a consistent core to his positions over the decades of his career, most now accept to a greater or lesser extent that Burke was a career politician and had to react pragmatically as well as on principle. Therefore the "microscopic context of quotidian politics," as Richard Bourke has put it, as well as the "intellectual context of eighteenth-century political thought" needs to be taken into account in order to understand Burke's ideas.7

Since the 1990 os historians of the turbulent French Revolutionary decade in British politics have increasingly complicated our understanding of radical reformist political thinking in the $1790 \mathrm{os}$. While the campaign for constitutional reform in that decade was already recognized to have been heterogeneous in its aims, ${ }^{8}$ a series of articles by Mark Philp in particular has challenged the lingering conviction that the British response to the revolution in France was more or less simply polarized rather than nuanced and complex. 9 He has, further, argued persuasively that even the political thinking of individuals in that decade was not necessarily settled and consistent or even coherent, and that we need to accept that the course of events and new

5. John Faulkner, "Burke's First Encounter with Richard Price: The Chathamites and North America," in An Imaginative Whig: Reassessing the Life and Thought of Edmund Burke, ed. Ian Crowe (Columbia, Mo., 2005), 93-126.

6. See Gary Browning, A History of Modern Political Thought: The Question of Interpretation (Oxford, 2016), 67-88.

7. Conor Cruise O'Brien, The Great Melody: A Thematic Biography and Commented Anthology of Edmund Burke (London, 1993); Richard Bourke, Empire and Revolution: The Political Life of Edmund Burke (Princeton, N.J., 2015), 18.

8. E.g., H. T. Dickinson, Liberty and Property: Political Ideology in Eighteenth-Century Britain (London, 1977), 232-69.

9. Mark Philp, "The Fragmented Ideology of Reform," in The French Revolution and British Popular Politics, ed. Philp (Cambridge, 1992), 50-77; Philp, "English Republicanism in the 179os," Journal of Political Philosophy 6 (1998): 235-62; Philp, "Preaching to the Unconverted: Rationality and Repression in the 179os," Enlightenment and Dissent 28 (2012): 73-88; Philp, "Disconcerting Ideas: Explaining Popular Radicalism and Popular Loyalism in the 1790s," in Reforming Ideas in Britain: Politics and Language in the Shadow of the French Revolution (Cambridge, 2013), 71-101; Philp, "Talking about Democracy: Britain in the 1790s," in Re-imagining Democracy in the Age of Revolutions: America, France, Britain, Ireland 1750-1850, ed. Joanna Innes and Mark Philp (Oxford, 2013), 101-3. See also Olivia Smith, The Politics of Language 1791-1819 (Oxford, 1984); and Amanda Goodrich, "Radical 'Citizens of the World,' 1790-95: The Early Career of Henry Redhead Yorke," Journal of British Studies 53 (2014): 611-35. 
ideas caused the political ideas of individuals to shift. ${ }^{10}$ Even where their own ideas did not change, they were highly conscious of "the boundaries of the politically possible and the politically desirable." 11 Moreover, as Olivia Smith, James Epstein, and David Eastwood have demonstrated, the transience and mutability of language needs to be attended to in a moment of political anxiety and social unrest. ${ }^{12}$ While the tensions of the 179 os were notoriously powerful, it is worth considering whether similar pressures may have operated on those who were persuaded of the case for political change in the earlier period of the American crisis. They, too, may have struggled to articulate from the outset a settled perspective that remained unaffected by events or by the various audiences to whom they wrote and spoke.

This model suggests a key to understanding Price's discussions of the American Revolution, also exemplified by Michael Brown's study of Dugald Stewart, professor of moral philosophy at the University of Edinburgh. Brown proposes that the problem of understanding Stewart's apparently varying political opinions in the 1790 can be resolved by examining separately the different forums in which he discussed politics in that decade. ${ }^{13}$ He showed that Stewart did not retreat into intellectual and political blandness under stress. Rather, the philosopher dealt deftly with the difficulty of maintaining his admiration for radical campaigners such as William Drennan of the United Irishmen, at a time of great pressure to conform to conservative loyalism, by writing more and less guardedly in different media and for different audiences. Reformist attitudes, Brown suggests, should be seen as relational. In this view, a skillful operator such as Stewart, rather than being buffeted by the storms and tides of the decade, navigated difficult waters by knowing what could be articulated and to whom. A third suggestive example from recent writing on the 1790 is Jon Mee's valuable illumination of different dimensions and conventions of "conversation" in the late eighteenth century, and the varying codes of acceptable conduct for expressing disagreement with different interlocutors. "Frequently," he concludes, "the conversable worlds of the eighteenth and early nineteenth centuries did shut down risk in the name of the reciprocal matching of minds with minds." Yet the conversations he examines in one form or another also involved space for collisions, misunderstandings, resistances, and silences. ${ }^{14}$

10. Mark Philp, "Time to Talk," in Reforming Ideas in Britain, 287-311.

11. Philp, "Fragmented Ideology of Reform," 37.

12. Smith, Politics of Language; James Epstein, Radical Expression: Political Language, Ritual and Symbol in England, 1790-1850 (New York, 1994); David Eastwood, "Robert Southey and the Meanings of Patriotism," Journal of British Studies 31 (1992): 265-87; Jon Mee, "Rough and Respectable Radicalisms," History Workshop Journal 56 (2003): 238-44.

13. Michael Brown, "Dugald Stewart and the Teaching of Politics in the 179os," Journal of Irish and Scottish Studies 1 (2007): 87-126.

14. Jon Mee, Conversable Worlds: Literature, Contention, and Community, 1762 to 1830 (Oxford, 2011), e.g., 15-16, 137-67. 
This essay argues that a related resolution to the question of Richard Price's views on the American Revolution in the 1770 os and 1780 os is convincing. The French Revolutionary decade was undoubtedly an extreme period for political pressure and pace of events, but the years of the American crisis posed comparable problems for political thinkers with progressive sympathies - perhaps particularly so for individuals, such as Price, who by temperament valued consensus and disliked discord. Like Stewart, Price was an intelligent political operator. John Faulkner's sensitive reading of Burke and Price in 1790 once more emphasizes the need to situate them in their immediate political context. ${ }^{15}$ Recent careful thinking on the discussion of political ideas in the 179 os may therefore shed light on issues raised by political writings of the 1770 s and 1780 s.

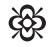

The gap between the radical Whig position that welcomed American independence (even some years into the conflict) and the parliamentary Whig attitude that merely sympathized with the colonists' plight was substantial. So too was the gulf between those who viewed the new United States as an asylum for those persecuted under the corruption of the British political system and those who regarded it principally as a collection of seceded colonies. A third point of division between varieties of proAmericanism was how the future international role of the United States was envisaged. Whereas radical pro-Americans came to view the new republic as a model or example to the rest of the world, parliamentary Whigs (whether Chathamite, Shelburnite, or Rockinghamite) saw it at best as a benign force in the world that might play a supporting role in the promotion of British international purposes. These were not simply degrees of difference, but substantive divergences in how individuals understood the nature of the revolution in America and, ultimately, in how they understood the political character not only of America but also of Britain. The case for viewing Price as a Shelburnite over the American question can be made by examining his relationships with both Shelburne and Chatham, the closeness of the moderate pro-American position to radical pro-American thinking in various respects, Price's support for a federal solution to the crisis, and his views on slavery.

Price's relationship with Shelburne was close. He was a member of Shelburne's Bowood circle from 1771 as a result of Shelburne's admiration for his theological publications. He acted as an adviser to Shelburne on religious, financial, and political issues, and in return Shelburne acted as patron to Price, giving him access to official statistics and to important figures such as the Earl of Chatham, the leader of Shelburne's parliamentary group. Price was also attached to other members of that group,

15. John Faulkner, "Burke's Perception of Richard Price," in The French Revolution Debate in English Literature and Culture, ed. Lisa Plummer Crafton (Westport, Conn., 1997), 1-25. 
such as Colonel Isaac Barré. ${ }^{16}$ Price and Shelburne both attended a Friday evening club together with such thinkers and writers as Hester Chapone, Elizabeth Montagu, and John Burrows. ${ }^{17}$ The two men corresponded with each other on relatively familiar terms: "I write to you upon my Knee," Shelburne informed Price on December 26,1774 , "in the midst of the Children's Noise, a very unfit Situation to write upon such Serious Subjects" as the "Address to the King" from the American Continental Congress of October 26, 1774. ${ }^{18}$ Shelburne asked Price to help him find a tutor for his sons, and Price both looked for openings for other protégés of the earl, and passed patronage requests from third parties on to Shelburne. ${ }^{19}$ Shelburne read and commented on papers and pamphlets that Price wrote, while Price dedicated the third and later editions of his Observations on Reversionary Payments (1773) to Shelburne. Price even endorsed Shelburne's 1776 plan for conciliating the Americans in his own Observations on the Nature of Civil Liberty of the same year, despite his own considerable discomfort with some aspects of it, notably its insistence that any agreement would continue to "prescribe" Britain's unquestioned right to regulate transatlantic commerce. As Faulkner points out, Price's concessions to Shelburne's argument were inconsistent with the bolder recommendations in his pamphlet. ${ }^{20}$ On the other hand, as Frank O'Gorman notes, Price did influence Shelburne's support for causes such as the reform of parliamentary representation and the maximum length of parliaments. $^{21}$

As an Arian minister, Price was not included in the terms of the Toleration Act of 1689, and he was grateful to both earls for supporting in the House of Lords the Dissenters' appeals in 1772 and 1773 against subscription to the Thirty-Nine Articles

16. Oxford Dictionary of National Biography [ODNB], s.v. "Price, Richard (1723-1791)," by D. O. Thomas, last modified May 26, 2005, https://doi.org/10.1093/ref:odnb/22761; Price to Shelburne, October 4, 1782, CRP, 2:145: "I love him [Barré], and my feelings for him on this occasion [an attack of blindness] are such as I cannot express."

17. CRP, 1:5on11.

18. Faulkner, "Burke's First Encounter with Richard Price," 111; Earl of Shelburne to Richard Price, December 26, 1774, CRP, 1:180.

19. Price to Shelburne, May 22, 1771, CRP, 1:97-98; Price to George Walker, [MarchMay 1771], CRP, 1:99; Price to Priestley, [December 1771], CRP, 1:125; Priestley to Price, July 22, 1772, CRP, 1:132-34; Price to Shelburne, October 31, 1772, CRP, 1:145-46; Price to Shelburne, July 24, 1779, CRP, 2:47-48. Cf. Thomas, The Honest Mind, 145-47.

20. Richard Price, Two Tracts on Civil Liberty, the War with America, and the Debts and Finances of the Kingdom: With A General Introduction and Supplement (London, 1778), in Richard Price: Political Writings, ed. D. O. Thomas (Cambridge, 1991), 14-100 at 73; Price to Shelburne, January 22, 1776, CRP, 1:238-39; Faulkner, "Burke's First Encounter with Richard Price," 111-13.

21. Frank O'Gorman, "Shelburne: A Chathamite in Opposition and in Government 1760-82?," in An Enlightenment Statesman in Whig Britain: Lord Shelburne in Context, 17371805, ed. Nigel Aston and Clarissa Campbell Orr (Woodbridge, U.K., 2011), 117-40 at 128-30; cf. Price to Shelburne, May 21, 1782, CRP, 2:125; Price to Shelburne, September 18, 1782, CRP, 2:144. Emmanuelle de Champs's essay in the same Aston and Orr volume, "Jeremy Bentham at Bowood," 233-47, presents a fascinating comparative case to Price's relationship with Shelburne. 
of the Church of England, campaigns in which he was centrally involved. ${ }^{22}$ Price also expressed appreciation to Chatham for proposing in the House of Lords that British troops should be removed from Boston in January 1775 and for attempting to persuade the government to conciliate the colonists in February 1775. He did so in strikingly deferential language, even allowing for the formalities of eighteenth-century letter writing:

I am shocked when I think that I am now perhaps interrupting your Lordship by an insignificant applause which it is impertinent in me to offer, and which it will be too indulgent in your Lordship to excuse. But I have, on some former occasions, experienced your condescension; and under an encouragement arising from hence, and with great regard, I beg leave to subscribe myself, my Lord. ${ }^{23}$

Price's relationships with Shelburne and Chatham during the period of the American Revolution were therefore not merely pragmatic: their thinking on the crisis in America as well as on other issues overlapped significantly with his own. Price and Shelburne clearly enjoyed discussing American affairs together: "the News" from America was growing "more and more interesting," and they looked forward, when constrained to communicating by letters, to each other's company when they could "talk more fully on these matters." 24 Both men regarded themselves as well-informed on American matters, and both were, as Shelburne put it, anxious to prevent "Injustice being done to the Principles and Intentions of Our American Brethren." 25 Moreover, as Faulkner points out, Chatham attracted extraparliamentary London supporters who were more radical than Rockingham's precisely because of some of his views on American policy, such as his insistence that the Americans ought not to be taxed by the British Parliament without being represented in it, his opposition to parliamentary sovereignty over the American colonies as enforced by the Rockinghamite Declaratory Act (1766), and his hostility to the encouragement of Roman Catholicism supposedly contained in North's Quebec Act (1774). ${ }^{26}$ Shelburne, too, was in fact a relatively advanced "Friend of America." Price introduced the American traveler Josiah

22. Price to Shelburne, April 18, 1772, CRP, 1:126-28; Price to the Earl of Chatham, May 3, 1772, CRP , 1:129-30; Price to Chatham, May 22, 1772, CRP, 1:131; Price to Chatham, January 16, 1773, CRP , 1:155; Price to Shelburne, February 23, 1773, CRP, 1:155-57; Price to Chatham, March 11, 1773, CRP , 1:157-6o; Price to Chatham, April 3, 1773, CRP, 1:162-63; Price to Chatham, February 9, 1775, CRP, 1:187-88. On the terms of toleration, see Bernard Lord Manning, The Protestant Dissenting Deputies, ed. Ormerod Greenwood (Cambridge, 1952), 3-7.

23. Price to Chatham, February 9, 1775, CRP, 1:186-87 at 187; Paul Frame, Liberty's Apostle: Richard Price, His Life and Times (Chicago, 2014), 103.

24. Shelburne to Price, December 26, 1774, CRP, 1:180; Price to Shelburne, December 29, 1774, CRP, 1:181; Shelburne to Price, [January 1775?], CRP , 1:186.

25. Shelburne to Price, [January 1775?], CRP, 1:185-86 at 186.

26. Faulkner, "Burke's First Encounter with Richard Price," 99, 113-17. 
Quincy Jr. to him in December 1774 and, after two hours' conversation with the earl, Quincy concluded in his journal that Shelburne appeared to be "a very warm friend to the Americans" who believed that, if the Americans remained united, they would eventually achieve their aims - though what most American colonists aimed for in December 1774, it should be noted, was not yet independence from Britain. ${ }^{27}$

Price's views on America therefore coincided with the Chathamites' in various respects. They agreed that the war against America could harm Britain's economy. In a speech in the House of Lords in March 1778, Shelburne endorsed Price's view that the government endangered the welfare of the Bank of England by risking war against France as well as America. ${ }^{28}$ They also agreed that Britain's likelihood of winning the military conflict was slight, despite government assertions to the contrary. ${ }^{29}$ More importantly for the purpose of comparing their political views, both Price and the Chathamites blamed the British government for the Revolution. Both distrusted the government's sincerity in offering to conciliate the colonists, and both admired the Americans' "exertions of the spirit of liberty" on their own behalf. 30

It is fair to argue, as did Colin Bonwick, that a distinguishing mark of a radical analysis of the American Revolution was to examine it "in relation to the general principles of civil liberty as well as the narrower grounds of particular problems and circumstances." Nonetheless, more moderate "Friends of America" also drew parallels between the American case and the state of the British constitution. Chatham himself did so as early as January 1766, in his speech calling for the repeal of the Stamp Act. Denying the government's assertion that American colonists were virtually represented in the British Parliament, he argued that not only were colonists not represented but even subjects who lived in Britain were seeing their representation steadily eroded:

That to say America was virtually represented was a nonsensical absurdity, that the people here were taxed by a virtual representation, that the best representation was that of counties, and that of great cities but as for the lesser boroughs he was confident their right to send representatives would in less than a century be amputated; that he came in support only that American liberty was as dear to him as Englishmen. That this country was at its last gasp. ${ }^{31}$

27. Price to Quincy, December 9, 1774, CRP, 1:178n1.

28. Frame, Liberty's Apostle, 131, citing Shelburne's speech in the House of Lords, March 13, 1778, as reported in the Gentleman's Magazine 48 (1778): 103.

29. Shelburne to Price, September 24, 1777, CRP, 1:260; Price to Shelburne, October 31, $1778, C R P, 2: 27-28$.

30. Price to Henry Marchant, November 2, 1773, CRP, 1:164. See Price to Chatham, February 9, 1775, CRP, 1:187; Price to William Adams, February 11, 1778, CRP, 1:269; Reich, British Friends of the American Revolution, 77-84; and Peters, The Elder Pitt, 220.

31. Bonwick, English Radicals and the American Revolution, 93; William Pitt, speech in the House of Lords, January 14, 1766, reported by J. West to the Duke of Newcastle, in Proceed- 
Charles James Fox, by then a Rockinghamite Whig, came to believe that the American Revolution was a powerful link in a long chain of momentous events beginning with the Reformation and extending through the English Civil War and the Glorious Revolution, which all aimed to reduce executive power..$^{32}$ Richard Price told an American correspondent in 1775 that "Indeed the influence of the crown has already in effect subverted liberty here; and should this influence be able to establish itself in America, and gain an accession of strength from thence, our fate would be sealed, and all security for the sacred blessing of liberty would be destroy'd in every part of the British dominions." But it was a Shelburnite MP, John Dunning, who proposed the parliamentary motion in April 1780 that "the influence of the crown has increased, is increasing, and ought to be diminished." 33

Perhaps most tellingly, for several years Price himself did not publicly promote American independence, writing for instance somewhat opaquely in June 1777 that he keenly hoped that the result of the struggle would "prove favourable to the interest of general liberty and justice." 34 Indeed, in his Observations on the Nature of Civil Liberty (1776), he supported a federal solution to the crisis, which would have kept Americans at least loosely bound to the British empire under the king, though with their consent and with considerable autonomy. "The truth is," he wrote, "that a common relation to one supreme executive head, an exchange of kind offices, types of interest and affection, and compacts, are sufficient to give the British Empire all the unity that is necessary." 35 Price only seems to have explicitly embraced independence for America from sometime between 1778 and 1779, recognizing its inevitability by February 1778, after the military surrender at Saratoga the previous October. ${ }^{36}$ This strategy of apparent pursuit of reconciliation with America by whatever means possible kept Price out of trouble with the Chathamites, who refused to entertain the desirability of American independence. All Chathamites toed this line till the earl's death in May 1778, and Shelburne maintained it thereafter. Price's great friend Joseph Priestley had been among the earliest radicals to criticize the British government for taxing its American subjects without granting them parliamentary representation (in 1769) and to anticipate military conflict with the colonists (in 1774). But Priestley

ings and Debates of the British Parliaments Respecting North America 1754-1783, vol. 2, 17651768, ed. R. C. Simmons and P. D. G. Thomas (New York, 1983), 91 (emphasis in the original).

32. John Derry, Charles James Fox (London, 1972), 294-95, 309, 311, 321, 355, 365-66.

33. Price to Charles Chauncy, February 25, 1775, CRP, 1:189; John Dunning, motion in the House of Commons, April 6, 1780, in The Parliamentary History of England from the Earliest Period to the Year 1803, ed. William Cobbett, 36 vols. (London, 1806-20), 21:347.

34. Price to John Winthrop, June 15, 1777, CRP, 1:259.

35. Price, Two Tracts, 38, cf. 34; Thomas, Richard Price and America, 1; Thomas, The Honest Mind, 154; Bonwick, English Radicals and the American Revolution, 97-98; Frame, Liberty's Apostle, 118. tion, 108.

36. Thomas, The Honest Mind, 261; Bonwick, English Radicals and the American Revolu- 
was Shelburne's librarian, and so he was effectively silenced on the subject of America for the duration of the war. 37

Shelburne went on, however, to negotiate a generous peace with the United States in 1782-83 as foreign secretary and then prime minister. He did so at great cost to his political career but in keeping with his view of the Americans, which was less rigid than Chatham's. Price refused to become Shelburne's private secretary at the negotiations at Versailles, but he did offer his advice, both on America and on questions of government finance with freedom and directness both while Shelburne held power and once William Pitt the Younger had become prime minister. Price's three priorities, which he pressed on Shelburne on various occasions, were a peace settlement including the complete cession of independence to America, the repair of Britain's finances, and parliamentary reform. ${ }^{38} \mathrm{He}$ advised Shelburne on economic policy 39 and on the desirability of a strong commercial relationship between Britain and America. ${ }^{40} \mathrm{He}$ also gave Shelburne his opinions on local politics ${ }^{41}$ and on Dissenting politics and personnel; 42 and he passed on intelligence gained from his own wide network of correspondents. 43 He persuaded Shelburne to press neither the Loyalists' case for reparations from the new American government nor the British case against American fishing rights off Newfoundland. 44

Finally, Price's views on constitutional affairs and on slavery may perhaps weaken the case for characterizing him as radical in relation to America. He was not as thoroughgoing in his aims for parliamentary reform as campaigners such as Major John Cartwright: he did not insist on universal manhood suffrage, the payment of MPs, or the secret ballot. He was anxious that even the qualified franchise enshrined in the American federal constitution of 1787 was too wide. 45 It is true that Thomas Paine did not insist on universal manhood suffrage, either, until as late as 1795 and possibly not even then. ${ }^{46}$ However, unlike Price, Paine did demand the removal of

37. Jenny Graham, Revolutionary in Exile: The Emigration of Joseph Priestley to America, 1794-1804 (Philadelphia, 1995), 10; W. A. Speck, "Joseph Priestley's American Dream," Historian 73 (2002): 19; though see also Robert E. Schofield, The Enlightened Joseph Priestley: A Study of His Life and Work from 1773 to 1804 (University Park, Pa., 2004), 23-24.

38. Price to Shelburne, March 26, 1782, CRP, 2:115-17.

39. CRP, 2:148-49, 152-55, 155, 156, 157, 160-61, 164-65, 165-69, 170, 172, 174-75, 178-79.

40. $C R P, 2: 217$.

41. CRP, 2:122, 124-25, 131-32, 134-35, 138-40, 142, 143-44.

42. CRP, 2:125-26, 129, 140, 141-42, 147, 179 .

43. E.g., Price to Shelburne, September 16, 1782, CRP, 2:143.

44. Price to Shelburne, November 24, 1782, CRP, 2:155-56; Frame, Liberty's Apostle, 154.

45. D. O. Thomas, "Was Richard Price a Radical?", in Richard Price and the Atlantic

Revolution, ed. Chris Williams (n.p., 1991), 58-70 at 60-65.

46. Mark Philp, Paine (Oxford, 1989), 34; Philp, "Revolutionaries in Paris: Paine, Jefferson and Democracy," in Paine and Jefferson in the Age of Revolutions, ed. Simon P. Newman and Peter Onuf (Charlottesville, N.C., 2013), 137-60; Gary Kates, "From Liberalism to Radicalism: Tom Paine's Rights of Man," Journal of the History of Ideas 50 (1989): 569-87. 
the monarchy and the aristocracy. 47 Price established strong friendships and sympathies with relatively moderate American politicians such as John Adams. ${ }^{48}$

Moreover, Anthony Page has argued that Price was "in many ways a passive abolitionist." He even allowed for the compromise of a gradual abolition of slavery in his Observations on the Importance of the American Revolution (1784), where he was at his most vehement against enslavement, and he later became still less insistent in the face of southern hostility to his remarks. Price, Page argues, was daunted by the scale of the problem; he perhaps did not wish to offend his numerous American friends; he feared unsettling the union of states, which he well knew to be fragile, not least over this very issue; and ultimately, his social attitudes were perhaps less radical than his philosophical and political ideas. 49 Jefferson, who encouraged him to remain firm in his abolitionist stance, invited him in 1785 to write an address for the students at the William and Mary College in Virginia on the question of abolition, but Price declined to do so, on the somewhat evasive grounds of old age and what he said was his desire to write only about "Divinity and Morals" at that stage in his life.50

\section{隽}

The preceding argument is challenged, however, by the chief difficulty for categorizing Price as a Shelburnite on America, which is his major disagreement with Shelburne's public position on the desirability of American independence, a divergence that became clear from 1778. Refusal to concede the acceptability of American independence had been a central tenet of Chatham's position, a stance from which Shelburne did not publicly or clearly deviate until independence was a fait accompli. The case for Price as a radical pro-American is further built on his relationships with leading radical politicians in both America and Britain; his justification of the American Revolution; and his discussions of the peace, the Anglo-American relationship, and the development of the United States of America after 1783. In all of these respects he went considerably further than any Chathamite politician, including Shelburne.

First, Price was probably as well connected with a network of American correspondents as any Briton, and certainly much better connected than any other

47. Pocock, "Radical Criticisms of the Whig Order," 46.

48. Thomas, Richard Price and America, 26-27; Price, The Evidence for a Future Period of Improvement in the State of Mankind, with the Means and Duty of Promoting It (London, 1787), in Richard Price: Political Writings, ed. Thomas, 152-75 at 164n18; Benjamin Franklin, Arthur Lee, and John Adams to Price, December 7, 1778, CRP, 2:29-30; Price to [Arthur Lee], January 18, 1779, CRP, 2:36.

49. Anthony Page, "'A Species of Slavery': Richard Price, Rational Dissent and Antislavery," Slavery and Abolition 32 (2011): 53-73 at 55. Cf. Christopher Leslie Brown, Moral Capital: Foundations of British Abolitionism (Chapel Hill, N.C., 2006), 149-50, 201.

50. An ambition Price of course put aside in November 1789 to write his Discourse on the Love of Our Country. Jefferson to Price, August 7, 1785, CRP, 2:299; Price to Jefferson, October 24, 1785, CRP, 2:313. 
Chathamite. If he was a Chathamite or even a Shelburnite, he was an outlier in this respect. He maintained a close friendship with Benjamin Franklin from at least 1762 until Franklin's death in 1790 , rooted in shared interests in science and moral philosophy as well as in politics. Paul Frame argues that Franklin was critical to the development of Price's thought on America. ${ }^{51}$ Price's depth of affection for John Adams is similarly evident. Price met some of his other long-standing American friends-Charles Chauncy, Arthur Lee, Henry Marchant, Josiah Quincy Jr., Ezra Stiles, and John Winthrop-through his writing on theology and public finance rather than through politics, although some of them, on their occasional visits to London, visited the Club of Honest Whigs, of which he and Franklin were central members. The warmth of Price's friend ships with his American correspondents is apparent in their taking any secure opportunity to be in touch during the conflict, although they largely avoided writing out of concern for one another's safety. 52 Price nurtured his network as well as he could, given these constraints; he was anxious to know how his friends were as the war progressed. The few letters he did receive usually contained news of other friends and sometimes American newspaper articles, and his own letters passed on good wishes, well-meant gossip, and often books for mutual friends. ${ }^{53} \mathrm{He}$ sent his American correspondents copies of his political pamphlets and visited those who became prisoners of war in England (Henry Laurens and John Trumbull).54 After the war, Price wrote frequently to American friends on behalf of British emigrants to the United States-relatives of members of his London congregation, writers, and intellectuals-asking for their support and help for these individuals.

Relationships with a large number of American correspondents had a similar effect on the views on American independence of Rev. Dr. John Erskine, the leading Church of Scotland evangelical and author of Shall I Go to War with My American Brethren? (1769) and other pro-American pamphlets. He and Price were poles apart theologically, and they were not very proximate politically, but both men had unusually substantial American correspondence networks long before the development of the imperial crisis-in Erskine's case, since the mid-1740s. These relationships proved more important than political considerations for Erskine, who found it impossible to oppose the Americans when they separated from the British empire.55 In Price's case, his friendships were probably similarly formative, even if he was more politi-

51. Frame, Liberty's Apostle, 81-87, 92; cf. Thomas, The Honest Mind, 142-45.

52. Price to Baron J. D. van der Capellen, January 25, 1779, CRP, 2:38.

53. E.g., CRP , 1:229, 246, 259; 2:216, 218, 221, 225, 231, 232, 233-34, 235; Rémy Duthille, "Dissent against the American War: The Politics of Richard Price's Sermons," in War Sermons, ed. Gilles Teulié and Laurence Lux-Sterritt (Newcastle-upon-Tyne, U.K., 2009), 130-48 at 141.

54. E.g., CRP, 2:38, 53, 54, 80, 86, 110, 114, 122-23, 136-38, 146-47, 152.

55. Jonathan M. Yeager, Enlightened Evangelicalism: The Life and Thought of John Erskine (New York, 2011), 141; John R. McIntosh, Church and Theology in Enlightenment Scotland: The Popular Party, 1740-180o (East Linton, U.K., 1998), 157-6o. 
cally predisposed to support the American struggle than Erskine. ${ }^{6}$ Like Erskine, he developed close friendships with people whose perspective he was increasingly likely to defend as their attachment deepened: "My heart is indeed with [them], and I am continually attending to the accounts of what passes among them." 57 Price became exceptionally well informed about political developments in America and, as D. O. Thomas pointed out, he was advised by correspondents who, to a man, supported the rebel cause.$^{8}$ Price asked very specific questions, and they sent him detailed information during and after the Revolutionary crisis and war. This gave him a different perspective from that offered by official British reports, and he was impatient with British statesmen and officials who were not adequately informed about America. "Our affairs with the American states seems [sic] also in a bad train," he complained to Shelburne in May 1784. "If I am rightly informed, there is a greater probability of a commercial war than a commercial treaty with them; and the majority of the [Privy] Council are under the influence of the most miserable mis-information with respect to them." 59

Price, then, continued to be profoundly concerned with the progress of the new American republic after the end of hostilities, unlike either the Chathamites or the Rockinghamites, those ci-devant "Friends of America" who had surprisingly little to say about the new republic for a decade after the peace was signed.60 "From what I have said," he told Benjamin Rush in June 1783, "you must conclude that I cannot but be deeply interested in all that is now passing in America; and that, therefore, it will be highly agreeable to me to be informed of any transactions there. Any information of this kind will be gratefully received." 61 Price's sustained focus on America may have been a significant disjunction from the Chathamites, but it does not necessarily place him in the radical camp. John Erskine had a similar substantial and continuing interest in the new republic, for example, but although he was deeply opposed to British policy in America during the Revolutionary crisis, he was committed to conciliation and only reluctantly accepted the need for American independence when it became clear that conciliation was not an option. He sympathized with the predicament of the Americans rather than with the aims of the Patriots. ${ }^{62}$ A wealth of knowledge of and an abiding interest in the American situation, born of a rich network of

56. Frame, Liberty's Apostle, 98.

57. Price to Henry Marchant, November 2, 1773, CRP, 1:164.

58. Thomas, Richard Price and America, 13.

59. Price to Shelburne, May $8,1784, C R P, 2: 217$.

6o. F. P. Lock, Edmund Burke, vol. 2, 1784-1797 (Oxford, 2006), 55; J. N. Rakove, "Why American Constitutionalism Worked," in Edmund Burke: Reflections on the Revolution in France, ed. F. M. Turner (New Haven, Conn., 2004), 248-67.

61. Price to Rush, June 26, 1783, CRP, 2:186.

62. Yeager, Enlightened Evangelicalism, 158-62; Henry Moncrieff Wellwood, Account of the Life and Writings of John Erskine (Edinburgh, 1818), 163-64, 266-81, 399. 
correspondents and friends, might suggest a disposition to radicalism on the issue of America, but it was not sufficient to determine it.

Price, however, was embedded not only among the Chathamites and leading American Patriots but also, unlike John Erskine, among London radical politicians. He may not have been a political activist to the extent of men such as John Wilkes, John Jebb, John Cartwright, John Thelwall, or Thomas Hardy, but he was certainly a central figure in their circles. ${ }^{63}$ As well as attending regularly the Club of Honest Whigs, mentioned above, he was a founding member of the Society for Constitutional Reform (1780), a founding member of the Society for Constitutional Information (1780), and active in the Society for Commemorating the [Glorious] Revolution in Great Britain (better known as the Revolution Society). ${ }^{64} \mathrm{He}$ collaborated politically or was on close terms with men such as John Horne Tooke, Joseph Priestley, Andrew Kippis, John Canton, James Burgh, and Thomas Paine, as well as with more moderate politicians such as Christopher Wyvill. 65

Shelburne was also closely connected with London Dissenters and politically active merchants and bankers, however. ${ }^{66}$ Thus it is Price's views on the justification of the American Revolution and on the role of America thereafter that most securely identify him as a radical with respect to America. In these he was closer to sympathizing with the American Patriot perspective than any Chathamite or Shelburnite politician. ${ }^{67}$ Shelburne was certainly more attentive to American concerns and sensitivities than many of his Chathamite colleagues-for instance while in his position inside the Chatham administration of $1766-68$, and while in opposition in response to the Boston Tea Party and the Coercive or Intolerable Acts. ${ }^{68}$ But attentiveness was entirely different from genuine support for what became the cause of the American colonists after 1775. James Caudle has argued that Price did not wait until his infamous Discourse on the Love of Our Country in 1789 to argue that resistance to government was permissible even before a last resort, but that he had already made the same case from as early as the American war. In 1775, he wrote that "The Colonies, therefore, should be upon their guard against insidious offers; and consider this as their time for securing forever their liberties... The stake is vast and worth any temporary suffering." 69 He developed this point in his Sermon Delivered to a Congregation of Protestant Dissenters, at Hackney in February 1779, arguing that, where other means

63. Jack Fruchtman, The Apocalyptic Politics of Richard Price and Joseph Priestley:

A Study in Late Eighteenth-Century English Republican Millenarianism (Philadelphia, 1983), 105.

64. See ODNB, s.v. "Price, Richard (1723-1791)"; Frame, Liberty's Apostle, 85, 142.

65. Frame, Liberty's Apostle, 86, 142-43, 245, 266.

66. Thomas, Richard Price and America, 9.

67. Thomas, The Honest Mind, 151-60.

68. Peters, The Elder Pitt, 179, 216-18.

69. James Caudle, "Richard Price and the Revolution in Resistance Theory, 1770-1790," in Consortium on Revolutionary Europe 1750-1850: Selected Papers (Tallahassee, Fla., 2000), 55-66; Price to [James Bowdoin], [October 1775], CRP, 1:232. 
of reform and the expression of grievances proved inadequate, even violent resistance could be justified. 70 This was a view significantly more progressive than the majority Whig position of reluctant vindication of resistance as the last recourse.

Although Price made the case for a federal solution to the American crisis in his 1776 pamphlet, Observations on the Nature of Civil Liberty, he also claimed there that government was "an institution for the benefit of the people governed, which they have the power to model as they please." This was, he believed, the foundation of liberty. ${ }^{71}$ Crucially, as D. O. Thomas argued, Price defended the right to self-government not only in terms of an entitlement to representative government, as Chatham did, but also in terms of the claim to national autonomy. ${ }^{72}$ "The ardent wish of my heart," he wrote in 1780, "is that every country under heaven may enjoy the blessings of liberty and independence." He ridiculed ministerial assertions that the Americans had turned against the desire for independence. 73 Unlike Chatham, he made no distinction between a people's right to consent to taxation by means of representation and their right to consent to all legislation. 74

Most significantly, despite his original reluctance to promote the absolute separation of America from the British empire, as the conflict progressed he gave every sign of hoping for an American victory. This is difficult to reconcile with the Chathamite, or even Shelburne's, perspective. In his Additional Observations on the Nature and Value of Civil Liberty (1777), after asserting that the "equality or independence of men is one of their essential rights," he continued: "It is the same with that equality or independence which now actually takes place among the different states or kingdoms of the world with respect to one another. Mankind came with this right from the hands of their maker." 75 His preference for retaining the imperial link in the first few years of the crisis was entirely typical of British radicals. The federal solution had been proposed as late as 1773 and in the Massachusetts House of Representatives by none other than Benjamin Franklin, so that Price's advocacy of it before 1778 does not necessarily identify him as a moderate on America. Even in 1775 Franklin was repudiating the desirability of independence to the Earl of Chatham. ${ }^{76}$ But by 1779 Price was noting with pleasure to his Dutch correspondent that "There seems at present no danger of the subjugation of America. There, I trust, a government of peace and liberty and virtue will be established." 77 In January 1782 he wrote to Franklin, "I rejoyce

70. Caudle, "Richard Price and the Revolution in Resistance Theory," 63-64.

71. Price, Two Tracts, 27, 22-23.

72. CRP, 2:xiii; Thomas, The Honest Mind, 187-213.

73. Price to [Francis Dana], September 26, 1780, CRP, 2:79.

74. Faulkner, "Burke's First Encounter with Richard Price," 114.

75. Price, Two Tracts, 86.

76. Faulkner, "Burke’s First Encounter with Richard Price," 115; Frame, Liberty’s Apostle, 92,118 .

77. Price to Baron J. D. van der Capellen, May 28, 1779, CRP, 2:43. 
heartily in the security which an object which has been long a favourite one with me, seems lately to have received." 78

Indeed, Price himself was unable to reconcile his attitude to American independence with Shelburne's. He was conscious that even in his Observations on the Nature of Civil Liberty, in which he endorsed Shelburne's plan for conciliation, he had probably "carried my Ideas in it higher than your Lordship can approve."79 On March 5, 1778, Shelburne told the House of Lords that he would "never consent that America should be independent," since American independence would result in the setting of Great Britain's sun. ${ }^{80}$ On March 21, convinced that cession of independence was now vital, Price set out to the earl the pragmatic justification for the opposite case. He emphasized the imminent Franco-American alliance and the necessity of retaining a good commercial relationship with the Americans, but he recognized delicately that Shelburne would not find this advice palatable: "In offering these sentiments I have perhaps taken an improper liberty; but I have meant to perform an act of friendship, and I know I can rely on your Lordship's indulgence and candour." 81 Sending his advice to the earl upon Shelburne's entrance to government office four years later, he pressed "the acknowledgement of the independence of America" on Shelburne as a prerequisite to a general peace. "I mention this with pain," Price wrote, four years after the breach in their convictions had emerged plainly, "nor can I enough regret the difference of opinion between us about it. So different are our opinions in this instance, that what your Lordship reckons a calamity will, I think, be a blessing to America, to us and to the world." 82

Price's hopes for Anglo-American relations after the end of the war also went beyond Shelburne's admittedly progressive desire to establish a strong trading connection with the United States. ${ }^{8} 3$ Price did indeed wish for such a commercial understanding to be developed, but not only did he desire transatlantic commerce "to be as free and open as it was before the war," he also wished for a much more substantial transatlantic connection than had existed before the war. ${ }^{84} \mathrm{He}$ was not entirely unrealistic:

78. Price to Franklin, January 7, 1782, CRP, 2:113-14.

79. Price to Shelburne, January 22, 1776, CRP, 1:239. Compare also their ideas on political reform in Ireland: Martyn J. Powell, "Shelburne and Ireland: Politician, Patriot, Absentee," in Enlightenment Statesman in Whig Britain, ed. Aston and Orr, 141-59 at 158.

8o. Shelburne, speech to the House of Lords, March 5, 1778, in Parliamentary History, ed. Cobbett, 19:850. Nor did he speak in these terms merely to please Chatham; in December 1778, seven months after Chatham's death, he vowed "never [to] serve with any man who would either maintain it was right, or consent to acknowledge the independency of America"; Shelburne, speech to the House of Lords, December 7, 1778, in Parliamentary History, ed. Cobbett, 20:40. See also Shelburne, speech to the House of Lords, February 7, 1782, in Parliamentary History, ed. Cobbett, 22:987.

81. Price to Shelburne, March 21, 1778, CRP, 1:273-75 at 275.

82. Price to Shelburne, March 26, 1782, CRP, 2:116.

83. John Ehrman, The Younger Pitt, vol. 1, The Years of Acclaim (London, 1969), 82, 93-95.

84. Price to Samuel Mather, July 22, 1784, CRP, 2:221. 
he told more than one hopeful correspondent in 1783 that he did not think requests for British subscriptions for the support of American colleges and churches were likely to be received sympathetically so soon after the war. Indeed, he thought that America now ought to "learn to take care of itself" (though he made many donations on his own account to American colleges and other academic institutions). ${ }^{85}$ What he really hoped for, however, was a transatlantic relationship that might be characterized as "a family compact" - a concept related to but much more informal than the federal empire for which he had earlier hoped. He now thought this compact preferable because of the great asset that he believed the independent America to be to the world. ${ }^{86}$ It would "render America more an advantage to us than ever," he told Shelburne; and he enlarged on his thinking in a letter to Ezra Stiles, president of Yale College:

The establishment of the independence of the united states gives a new direction to the affairs of the world; and will, I hope, prove the greatest blessing to it. This country, in particular, might be the greatest gainer by it, were it wise enough to reform its representation, and to study by all measures of conciliation, and, particularly, by consenting to a perfect reciprocity in all the intercourses of commerce, to bring about a family compact with the united states. In this way we might derive greater advantages from them than we ever derived from any dominion over them. ${ }^{87}$

Indeed, he went so far as to consider that the fact that the British government under Pitt the Younger appeared to be uninterested in a reciprocal trade agreement with the United States, although "sad policy in Britain," was actually likely to turn out "to be best for America," which he believed ought to restrict its foreign trade as much as possible and rely on its own resources. ${ }^{88}$ Price was disposed not to mourn the separation of the colonies from Britain and then ignore them as best he could, but rather to desire a mature and mutually beneficial relationship with the independent republic and the flourishing of America regardless of Britain's own state. This attitude of detachment from traditional British imperial interests went too far for Chathamite

85. Price to Rush, January 1, 1783, CRP, 2:162-63; Price to Henry Marchant, October 6, 1783, CRP, 2:199-200; Price to Joseph Willard, July 23, 1784, CRP, 2:222-23; Price to Ezra Stiles, October 15, 1784, CRP, 2:236.

86. Price to Shelburne, [October 1784], CRP, 2:231.

87. CRP, 2:231; Price to Ezra Stiles, October 8, 1784, CRP, 2:233. Cf. Price to Jonathan Trumbull, the Elder, July 9, 1785, CRP, 2:291-92.

88. Price to Thomas Jefferson, March 21, 1785, CRP, 2:269; Price to Jonathan Trumbull, the Elder, July 9, 1785, CRP, 2:292; Price to Ezra Stiles, August 2, 1785, CRP, 2:297. See also CRP, 2:232-33; and Price, Observations on the Importance of the American Revolution and the Means of Making It a Benefit to the World (London, 1784), 74-80. 
thinking, but was characteristic of radical admiration for the United States as an independent polity.

Price was therefore in a position to play an almost formal role in American matters, unlike other Chathamites. During the war he identified so clearly with the American side that he passed information on trade and troop figures to Americans, which Frame suggests bordered on the treasonable, and he was well aware that his mail was likely to be under surveillance. ${ }^{89}$ Various Americans believed him to be an influential figure in Britain, asking him, for instance, to support their postwar claims for compensation. $9^{\circ} \mathrm{He}$ was offered American citizenship and a role as a financial consultant to the American government as early as October 1778 , together with monetary aid to move across the Atlantic with his family. He was proud of this honor, and, although he declined it on the grounds of old age and obligations in Britain, he remained wistful, saying later that "I wish I was capable of advising and assisting them."91 By "capable," he really meant "on the spot" rather than "able intellectually and experientially," as is clear from various letters written while he was composing his Observations on the Importance of the American Revolution (1784). Both the letters and the pamphlet, which he originally intended to be circulated only in America, demonstrate a sense of vocation to advise the United States. ${ }^{92}$

In his letter of 1779 refusing Congress's offer of citizenship and an advisory role, Price told its representatives that he saw the United States as "now the hope, and likely soon to become the refuge of mankind." 93 This was a view that he had formed by 1773 , when he told Henry Marchant, the attorney general of Rhode Island,

You are in a country that is increasing and improving fast, and likely in time to be the seat of the greatest and happiest empire that ever existed. I am in a country that is, I am afraid, declining. Corruption and venality have undermined the foundations of civil liberty among us; and as to religious liberty, allmost all that we enjoy of it is an indulgence or connivance contrary to law.... America is the country to which most of the friends of liberty in this nation are now looking; and it may be in some future period the country to which they will be all flying. 94

89. Frame, Liberty's Apostle, 131, 136-37.

9o. Jonathan Trumbull, the Elder, to Price, December 1, 1783, CRP, 2:204; Price to William Gordon, March 23, 1785, CRP, 2:269.

91. Price to Rush, June 26, $1783, C R P, 2: 185$.

92. Price to Franklin, April 6, 1784, $C R P, 2: 215$; Price to Franklin, July 12, 1784, $C R P$, 2:218; Price to Joseph Willard, July 23, 1784, CRP, 2:222; Price to Shelburne, [October 1784], $C R P, 2: 230$; Price to Jonathan Trumbull, the Elder, October 8, 1784, CRP, 2:232; Price to Stiles, October 15, 1784, CRP, 2:235.

93. Price to Franklin, Arthur Lee, and John Adams, January 18, 1779, CRP, 2:35.

94. Price to Marchant, November 2, 1773, CRP, 1:164. 
These twin ways of seeing America, as a flourishing exemplar to the Old World and as a refuge for the oppressed of the Old World, were repeated by Price in many letters and publications. 95 They mark him out as radical rather than Chathamite, first because he was considering the role of America in the world after independence at all, and second because he estimated the United States so highly. His opinion that the American Revolution was likely to prove "the most important step in the progressive course of improvement" of mankind since the emergence of Christianity was categorically radical. America opened "a new prospect in human affairs, and ... a new æra in the history of mankind”; its potential was vast. 96

His advice to the citizens of the new republic, gathered in his 1784 Observations but pondered repeatedly in his correspondence before, during, and after the writing of that work, once more distinguishes him as radical rather than Chathamite. For example, while both the moderate and radical "Friends of America" believed that the power of the executive in the British government was too great, one distinction between them lay in whether they wished to redress the balance in favor of popular or parliamentary sovereignty. Price was convinced of the need for popular sovereignty:

Government is an institution for the benefit of the people governed, which they have the power to model as they please; and to say that they can have too much of this power, is to say that there ought to be a power in the state superior to that which gives it being, and from which all jurisdiction in it is derived. 97

The new American constitution of 1787 pleased Price: it "meets my Ideas in most of its parts," he told Jefferson, and he was very pleased that it had been adopted..$^{8}$ He was convinced of the need for popular sovereignty, and he preferred a wide franchise, though he was pragmatic about its adoption. ${ }^{99} \mathrm{He}$ particularly valued religious

95. E.g., see $C R P, 2: 36,38,150,163,169,185,199,213-15,222,233,236,268$; Price, Two Tracts, 41, 71-72; Price, Observations on the Importance of the American Revolution, 2-7; Price, The Evidence for a Future Period of Improvement, 152-75 at 161, 164-65, 173; Price, A Discourse on the Love of Our Country (1789), in Richard Price: Political Writings, ed. Thomas, 176-96 at 195-96; Price's speech at the celebration of the first anniversary of the fall of the Bastille, held at the Crown and Anchor in the Strand on July 14, 1790, printed in D. O. Thomas, "Richard Price's Journal for the Period 25 March 1787 to 6 February 1791, Deciphered by Beryl Thomas with an Introduction and Notes by D. O. Thomas," National Library of Wales Journal 21 (1980): 366-413 at 399.

96. Price, Observations on the Importance of the American Revolution, 2-3, 5-6, 15; Two Tracts, 71-72. See Emma Macleod, British Visions of America, 1775-1820: Republican Realities (London, 2013), 9-27, for examples of other radicals who pinned their hopes for international progress on the independent United States; see also Dickinson, "Friends of America."

97. Price, Two Tracts, 27, cf. 28-29, 88; Faulkner, "Burke's First Encounter with Richard Price," 114-15; H. T. Dickinson, “The Eighteenth-Century Debate on the Sovereignty of Parliament," Transactions of the Royal Historical Society, 5th ser., 26 (1976): 204-5.

98. Price to Jefferson, October 26, 1788, CRP, 3:182-83.

99. Frame, Liberty's Apostle, 114, 144; Thomas, "Was Richard Price a Radical?" 70. 
liberty and he applauded the separation of church and state in the American colonies even before they declared independence and as it was enacted in various states after 1783. ${ }^{100}$ Price was, however, deeply anxious about how events would actually turn out in America, and he was better informed than many British "Friends of America," understanding the partial nature of various liberties - religious, social, and political-in the young republic. ${ }^{101}$ "I am sensible that the United States are a very heterogeneous mass, and that there is danger that events may not turn out as happy there as the friends of liberty and humanity in Europe earnestly wish," he wrote in 1785. Price's general hopefulness about the constitution was not mere utopianism, born of a radical's wish to see a model of a representative constitution for emulation, though Price was as prone to that as any other British radical. It was also a much more practical desire, based on his own financial expertise, which told him that America would be much more creditworthy as a new member of the world of nations if it were a federal union instead of thirteen or more separate states. ${ }^{102}$

It is not difficult, therefore, to make the case for Price's radicalism with respect to America. In his relationships with leading radical politicians in both America and Britain, in his justification of the American Revolution, and in his discussions of the peace, the Anglo-American relationship, and the development of the United States of America after 1783, he went considerably further than any Chathamite politician, including Shelburne. Especially after 1778 the volume of his public and private writings on America that supported American independence was far greater than that which was more cautious.

\section{踇}

Even if at his core, therefore, Richard Price was rather radical in his opinions on the American Revolution, it is perfectly feasible also to view him, in John Faulkner's words, as "to some extent a Chathamite." The suggestion that his views changed over time does not explain the case sufficiently. Price clearly made the argument for national autonomy in 1775 and 1776 , and yet he was also proposing a less complete break between metropolis and empire during those years. Price's preferred modus operandi in cases of profound disagreement, however, suggests the way to reconcile the apparently diverging opinions he expressed. He was both a skillful and pragmatic diplomat, and a man who preferred courtesy to acrimony. Like Dugald Stewart, he could temper the manner in which he expressed himself to his audience.

100. Price to Chatham, May 13, 1772, CRP, 1:129; Price, Two Tracts, 69; Price, Observations on the Importance of the American Revolution, 34-35, 46-49; Frame, Liberty's Apostle, 185; Thomas, Richard Price and America, 28-30; Thomas, The Honest Mind, 183, 279-80.

101. E.g., see CRP, 2:185-86, 199, 222, 234-35, 268-69, 293-94.

102. Price to William Gordon, March 23, 1785, CRP, 2:269-70. See also Price, Observations on the Importance of the American Revolution, 14-19, 66-68. 
It seems clear that Price was in fact at root radical rather than Chathamite or Shelburnite in his friendship to American liberty. First, he actively favored independence for the American colonists, rather than only coming reluctantly to acquiesce in it. Few pro-American British political commentators, radical or otherwise, ideally wanted the American colonies to depart from the British empire at the beginning of the crisis. Those who were more radical came more quickly to accept Patriot reasoning, as well as the military reality, and they made the political shift from acceptance to embrace of American independence, unlike either Chathamite or Rockinghamite politicians. They also, of course, unlike these statesmen, were unconstrained by the imperatives of office. This radical trajectory was Price's. Second, Price was convinced of the corruption of the British political system and saw America as an asylum for those persecuted under it from as early as 1773. These were both persuasions held much more deeply by radical politicians than by Chathamites (or, again, Rockinghamites). Third, even taking into account his anxiety that the United States might be falling prey to division and addiction to luxury, Price believed that it was undoubtedly an example for the rest of the world and that it had far overtaken Britain in progress toward an ideal of liberty. It was not merely a benign force in the world that might usefully be persuaded to play a supporting role in the promotion of British international purposes. Indeed, he thought America might even be better off if it did not become tied into a commercial relationship with Great Britain.

Price did not waver in these opinions, even when he disagreed with influential friends, such as Shelburne, to his great personal discomfort. In 1778, advising Shelburne that cession of independence to America was necessary, he was acutely aware that this was a touchy subject: but he did not back down, and restated his views firmly:

I have mention'd recognising the independence of America. To this I know, your Lordship is averse; and I am always grieved when I cannot adopt your sentiments. But situated, as this kingdom now is, I cannot, in the present case, entertain any doubts.... All real authority is gone; and it cannot be expected that by any nominal authority we can bind them to anything that interferes with their interest. In these circumstances, all hesitation about yielding independence to them seem $[\mathrm{s}]$ unreasonable. ${ }^{103}$

He returned to this subject in March 1782 when Shelburne entered government and the war had clearly been won by the Americans. Having acknowledged that Shelburne would find this advice disagreeable, he argued his case, both on the grounds of principle- "There is no worse slavery than the subjection of countries to one another" - and on the pragmatic grounds that a strong "family" relationship would benefit Britain more than expensive and violently imposed dominion. ${ }^{104}$

103. Price to Shelburne, March 21, 1778, CRP, 1:275.

104. Price to Shelburne, March 26, 1782, CRP, 2:116-17. 
The question of chattel slavery may be another case in point here. Price was indeed hurt and made anxious by the thought that he was becoming reviled in the southern states because of his condemnation of the institution and the practice in the United States in his Observations on the Importance of the American Revolution (1784). ${ }^{105}$ Yet he continued to express himself unambiguously on the subject thereafter. He told John Jay, the American secretary for foreign affairs, that, "Should a like disposition prevail in many of the other States" to that of southern slaveholders who had been offended by his strictures on slavery in his Observations,

it will appear that the people who have struggled so gravely against being enslaved themselves are ready enough to enslave others: the event which has raised my hopes of seeing a better state of human affairs will prove only an introduction to a new scene of aristocratical tyranny and human debasement: and the friends of liberty and virtue in Europe will be sadly disappointed and mortified. ${ }^{106}$

Price acknowledged that he was taking a risk in expressing himself so freely to Jay, and wondered whether the acquaintance he had struck up with Jay when he had been in London would stand the strain of his candor. ${ }^{107}$ Yet he did continue to stand his ground, and he wrote in very similar terms to Jefferson. In fact, it appears that he was less worried by the thought that he was becoming persona non grata in certain southern circles because of his opinions on slavery than by the thought that he had made himself look ridiculous to people in Europe by speaking so admiringly of the Revolution in America, because of the hypocrisy of the slave drivers yelping for freedom, as Samuel Johnson had put it nearly a decade previously. ${ }^{108}$

Anthony Page is right, however, that we might have expected a more substantial abolitionist track record from Price; and it is true that Price could appear gradualist, or more moderate than he at core was, in his thinking about an issue, not only on slavery but on the American Revolution more broadly. ${ }^{109}$ There are three reasons to be suggested for this appearance. It may, first, be a result of the fact, noted at some length above, that there was considerable overlap between radical and Chathamite thinking on various issues, such as the justification for the American Revolution, as well as between late eighteenth-century radical thought and older, Real Whig ideas. ${ }^{110}$ D. O. Thomas noted that it is necessary not to read Price through the eyes

105. Price, Observations on the Importance of the American Revolution, 83-84; Price to Rush, October 14, 1784, CRP, 2:234.

106. Price to Jay, July 9, 1785 , CRP, 2:293; Price to Jefferson, July 2, 1785, CRP, 2:29o.

107. Jay was always a firm opponent of slavery, so this is likely to have been an idiom of courtesy on Price's part.

108. Samuel Johnson, Taxation No Tyranny (London, 1775), 89.

109. Page, "'Species of Slavery.”

110. Thomas, "Was Richard Price a Radical?," 60-61, 66-67. 
of Edmund Burke in 1790 and thereby identify him as an unqualified natural-rights radical, or indeed through the discourse of later, more thoroughgoing natural-rights radicals. He was radical in relation to Whig thought (in his insistence on the right to self-government, the right to participate in government, and freedom of conscience), but less so in relation to the thinking of younger contemporary radicals (in his concern for prudence, balance, and prescription). ${ }^{111}$

Second, Price's appearance of gradualism or moderatism may also have been pragmatism or diplomacy. It was typical of him to accept an incremental advance over no advance at all and to work quietly toward his ideal goal. For example, whether or not he actually wanted universal manhood suffrage, as his endorsement of John Cartwright's call for it in Take Your Choice! (1776) suggests, Price certainly wanted a substantial widening of the British franchise, at least to all copyholders and freeholders. Yet, in May 1782, he was praising Shelburne's declaration "that you are for an equal representation of the kingdom," a plan the earl had promoted with others for shorter Parliaments, a somewhat wider county representation, and the abolition of rotten boroughs, which certainly amounted to less than Price ideally wanted. ${ }^{112}$ It may be that Price similarly settled for an incremental approach in discussing America with his Chathamite friends. Neither his pragmatism nor his diplomacy necessarily means he was not radical, though both may well mean he was an unusual radical politician in his mode of operation.

Finally, Price was generally much more open with correspondents who were "advanced" in their opinions, such as Franklin and other American Patriots, or with correspondents such as Jay and Jefferson who sympathized with an abolitionist position, than he was with Chathamites. This is not to imply that he blew with the wind, however. Rather, it is to suggest that being able to disagree civilly was extremely important to Price, and that this concern is a third possible explanation for why he can be seen as both a Chathamite and a radical on America. He did not mind disagreeing with his friends: he spent his working life in fields, after all, that thrived on controversy-economics, heterodox theology, and reformist politics. What he disliked immensely was when disagreement caused personal hostility and breaches of friendship. He did not, it has been suggested here, desist from maintaining and defending the opinions that caused him trouble. His assertions that he was unaffected by the abuse he received in Britain in response to his Two Tracts on Civil Liberty (1776-78) is belied by the frequency with which he made them, but he did not retract his pro-American opinions. ${ }^{113}$ Price was simply a man who preferred not to disagree when it was possible to agree. When it became impossible, he disagreed as courteously and as straightforwardly as possible, and then moved on. He is a good

111. Thomas, "Was Richard Price a Radical?", 68.

112. Price to Shelburne, May 21, 1782, CRP, 2:125; cf. O'Gorman, The Rise of Party in

England, 459-6o, note 3. See also Price to Shelburne, September 18, 1782, CRP, 2:144.

113. E.g., CRP, 1:252, 258, 259; 2:2, 23, 36, 42, 90-91. 
example of the tension between politeness and the growing commitment to the candid expression of ideas by "independent men" that has been identified by Martin Fitzpatrick and Matthew McCormack in radical reformers. ${ }^{114}$

Price famously argued trenchantly with his friend Joseph Priestley over the philosophical problem of free will and determinism. They corresponded at some length on the issue and then published their letters in 1778, precisely for the purpose of proving to the world that it was possible to disagree profoundly and yet amicably.115 Price wrote to Priestley shortly before the pamphlet was published:

It will afford a proof that two persons may differ totally on points the most important and sacred, with a perfect esteem for one another; and it may like wise give a specimen of a proper manner of carrying on religious controversies. There is nothing that offends me more than that acrimony of spirit with which controversies in general, and particularly religious ones, are commonly conducted. ${ }^{116}$

Similarly, in 1786 Price defended the value of religious debate to Shelburne (by then the Marquess of Lansdowne) as useful rather than harmful "when conducted with decency and temper."117

This approach often led Price to temper his remarks depending on his correspondents. Sometimes he moderated the tone of what he was saying rather than its content. To his friend William Adams, master of Pembroke College, Oxford, he wrote clearly but delicately about their disagreement on the question of American independence in 1781 , as the outcome of the war appeared increasingly evident: "Upon the whole... I reflect with much satisfaction on what I have done; and those of my friends who may differ from me will not, I hope, on this account withdraw from me their favourable opinion." 118 With others, however, Price was able to argue more robustly. In August 1785, writing to Ezra Stiles, he maintained his own preference for "the separation of civil policy from religion" against Stiles's opposite position, arguing that the consequences of the interference of the civil magistrates in matters of doctrine and church government had been "dreadful." This candor, expressed at some length, suggests that his friendship with Stiles was substantial and comfortable. ${ }^{119}$

114. Martin Fitzpatrick, "Varieties of Candour: Scottish and English Style," Enlightenment and Dissent 7 (1988): 35-56; Matthew McCormack, The Independent Man: Citizenship and Gender Politics in Georgian England (Manchester, 2005). (London, 1778). 115. A Free Discussion of the Doctrines of Materialism, and Philosophical Necessity

116. Price to Priestley, May 14, 1778, CRP, 2:21-22.

117. Price to Lansdowne, December 30, 1786, CRP, 3:105.

118. Price to William Adams, March 19, 1781, CRP, 2:98.

119. Price to Stiles, August 2, 1785, CRP, 2:296. 
Price suited the tone of his disagreement, therefore, to his correspondent, writing with deference to social superiors, and with respect and patience to his equals. He also moderated the content of his writing without changing his own mind about what was ideally desirable-often either choosing not to discuss points of disagreement or compromising to the point of gradualism. Rémy Duthille has pointed out that he did not always discuss his more controversial political views in church sermons, perhaps thinking that it would be inappropriate to do so in that setting and in any case expecting his congregation to be familiar with them from his publications. ${ }^{120}$ Similarly, in the extant correspondence, Price simply did not discuss the issue of American independence with Shelburne between making a clean breast in March 1778 and Shelburne's entry into government office in 1782. They discussed the progress of the war, the flaws in North's government, and the poor state of British finances instead-matters on which they easily agreed. In other circumstances, sometimes Price explicitly refused to take a correspondence further, or to meet a correspondent, when it became clear that agreement was very unlikely. ${ }^{121}$

An interesting exercise is to turn the argument advanced here around to ask whether Price was in fact at bottom a Shelburnite who had close friends among the radical pro-Americans and intellectual affinities with them on other issues, and who preferred not to press his views to the point of a breach of friendship if possible, but rather to spend time discussing issues where there was common ground. This hypothesis leaves too much to be explained, however. His correspondence and public writing from late 1778 onward was wholly supportive of American autonomy rather than preferring a federal solution. The enthusiasm with which he discussed independence with American patriots and other radical pro-American Britons is difficult to counter. It is not only possible but likely that he would genuinely have preferred a federal solution and only moved on to embrace independence when the continuation of the formal imperial tie became impossible-but nowhere did he express only acquiescence in events or less than warm enthusiasm for their denouement. There is no record of him disagreeing over the rupture with radical pro-Americans or American Patriots as he did with Shelburne, and he nowhere retracted his radical pro-American opinions.

It seems therefore that Richard Price was at core a radical pro-American. $\mathrm{He}$ was, however, intellectually as well as personally close to the Earl of Shelburne and his political circle, even if ultimately he differed from them on the most fundamental issues regarding the cause of the American colonies and was closer to the extra-parliamentary reformers in opinion. He was also a pragmatist and a skilled diplomat who took the opportunity of his influence with Chatham and Shelburne to argue for his views but who was clever or wise enough to press on them only what he thought he could achieve rather than the full extent of his ideal aims, most of the time. Finally, he simply did not

120. Duthille, "Dissent against the American War," 137.

121. See Price to Shelburne, October 4, 1782, CRP, 2:144; Price to Shelburne, November 20, 1782, CRP, 2:153, 154-55, for an example. 
like rifts in friendship, or even incivility. These characteristics, of pragmatic diplomacy and a preference for courteous disagreement-membership of a "conversable world," in Jon Mee's phrase, rather than of Thomas Paine's world of aggressive polemic-constituted Price's operating system for dealing with political, philosophical, or economic disputes with his friends. ${ }^{122}$ Together with the fact that there was substantial common political ground between radical and Chathamite "Friends of America," they explain why, although he was at core a radical on the American question, it is possible to read him as often holding considerable sympathies with both Chatham's and Shelburne's positions. These traits in Price and these features of the internal British dispute over America in the 1770 and 1780 os suggest that recent attempts to complicate our understanding of political debate and expression in the 1790 os are highly pertinent to the earlier period of crisis. It would be surprising if this approach were not also applicable to similarly sensitive thinkers and communicators at other moments of crisis and in other parts of the world, or indeed to political actors in times of change more broadly. By paying the kind of close attention to their language in relation to their varying interlocutors that historians of the 1790 s have recently done, the textures of their ideological positions may also be illuminated.

I would like to thank Dr. Yiftah Elazar and participants in the September 2015 conference at the Yale Center for the Study of Representative Institutions on "Revolution, Dissent and Democracy: The Political Thought of Richard Price," and also Professor Michael Brown, Dr. Diego Palacios Cerezales, and Dr. Gordon Pentland, for comments on earlier versions of this essay.

EMM A MACLEOD is a senior lecturer in history at the University of Stirling, Scotland. Her books are $A$ War of Ideas: British Attitudes to the Wars against Revolutionary France, 1792-1802 (1998), British Visions of America, 1775-1820 (2013), and Political Trials in an Age of Revolutions, co-edited with Michael T. Davis and Gordon Pentland (2019).

122. See also Philp, "Preaching to the Unconverted," esp. 78-79. 